\title{
Effects of the degree of milling on the quality characteristics of rice 'Nuruk'
}

\author{
Jeong-Sil Choi, Soo Hwan Yeo, Ji Eun Kang, Seok Tae Jeong* \\ Fermented Food Science Division, National Institute of Agricultural Sciences, Wanju 55365, Korea
}

\begin{abstract}
This study aimed to investigate the effects of the degrees of milling of rice (0-50\%) on the physicochemical properties and enzymatic activities of rice 'Nuruk'. As results, the contents of the general components of milled rice, except for the starch value (85.13-90.99\%) decreased as the degree of milling increased. The moisture content of rice with different degrees of milling ranged from 11.04 to $12.68 \%$ and significantly decreased as the degree of milling increased. Furthermore, the hydration rate increased as the degree of milling increased. The $\mathrm{pH}$ of rice 'Nuruk' was the lowest at 5.32 in the $0 \%$ milled rice 'Nuruk' and highest at 5.98 in the $30 \%$ milled one, which indicated no correlation between $\mathrm{pH}$ and degree of milling. By contrast, the soluble solid and reducing sugar contents which are correlated with the starch value of rice increased as the degree of milling increased. For the enzymatic activities of each rice 'Nuruk', there was no clear trend for the $\alpha$-amylase and acidic protease activities with respect to the degree of milling, whereas the glucoamylase activity decreased with increasing degree of milling. Correlation analyses indicated that the activity of glucoamylase decreased as the starch value of rice increased, but increased as the crude protein content of rice increased. The activity of acidic protease had a negative correlation with the crude lipid content of rice.
\end{abstract}

Key words : degree of milling, rice Nuruk, quality, rice, activities

\section{Introduction}

Milling is the process of removing the hull and bran from rice using a threshing machine and producing polished rice through a cleaning process. The degree of milling indicates the extent of milling by weight and the milling ratio (or $\mathrm{milled} /$ brown rice ratio) indicates the weight percentage of milled rice to brown rice. Although variations exist depending on the breed or cultivation region of rice, starch generally accounts for $75-80 \%$ of the rice grain by weight (Ahn and Ha, 2010; Lee, 2013). The outer layer of the grain consists of $7-8 \%$ protein, $1-3 \%$ fat, and vitamins and minerals (Lee et al., 2011). Therefore, the degree of milling is closely related to the quality of rice, and the fat and ash contents in the outer layer decrease as the degree of milling increases (Chun et al., 2012). Rice 'Nuruk' is a fermentation agent containing enzymes that can saccharify starch and is produced by inoculating steamed rice, which is a starch source, with fungi from a pure culture (Kwon et al., 2013). For fermented alcoholic beverages made from grain, the starch in the grain is converted into sugar and an alcoholic beverage is produced through the fermentation of such sugars. In this process, diastatic enzymes produced from microorganisms or grain are required; a primary source of such enzymes is 'Nuruk'. Hence, 'Nuruk' may be the most important factor that determines the fermentation efficiency and quality of alcoholic beverages (Park and Chung, 2014). As described above, there are generally numerous com-

*Corresponding author. E-mail : jst@korea.kr, Phone : +82-63-238-3615, Fax : +82-63-238-3843

Received 13 December 2019; Revised 10 January 2020; Accepted 13 January 2020.

Copyright (c) The Korean Society of Food Preservation.

This is an Open Access article distributed under the terms of the Creative Commons Attribution Non-Commercial License (http://creativecommons.org/licenses/by-nc/4.0) which permits unrestricted non-commercial use, distribution, and reproduction in any medium, provided the original work is properly cited. 
ponents other than starch in the outer layer of the grain such as protein, fat, and ash. Studies have reported that these components promote the growth of mold and yeast in addition to adding color to alcoholic beverages, wherein the chromaticity depends on the degree of milling (Chun et al., 2012; Kim et al., 2004). Because the degree of milling affects the quality of rice, variations in this process are likely to cause in the growth rate of microorganisms or the enzymatic activities, thereby affecting the quality of the 'Nuruk'. We hypothesized that the products of the mold vary depending on the conditions of 'Nuruk' fermentation. Such produces can thus affect the quality of alcoholic beverages. Therefore, in this study, we manufactured rice 'Nuruk', a fermentation agent that can affect the quality of alcoholic beverages, using different degrees of milling and examined the quality characteristics of the rice 'Nuruk'.

\section{Materials and methods}

\section{Materials and reagents}

Odaemi (a rice variety) produced at the Galmal Nonghyup general rice facility in Cheolwon, Gangwondo was used in this study. Polished Odaemi (moisture content: $12.68 \pm 0.16 \%$ ) was used as a reference (brown rice is used as a reference for the general milling ratio), and the rice was milled at 10\% (milled rice percentage (MRP) 90\%), 30\% (MRP 70\%), and 50\% (MRP 50\%) using the rice milling unit (Type 80824, Satake Corporation, Hiroshima, Japan). Here, the degree of milling was calculated as follows: degree of milling $=\{1-($ milled rice/polished rice $)\} \times 100(\%)$. The MRP was calculated as follows: MRP $=$ (milled rice $/$ polished rice) $\times 100(\%)$ (Liu et al., 2015). Rice 'Nuruk' (Aspergillus oryzae) was produced using mold starter $A$. oryzae $\left(20 \times 10^{9} / \mathrm{g}\right.$, moisture content less than $10 \%, 30$ saccharogenic power (SP)) (Chung Moo Fermentation Co., Woolsan, Korea). The reagents used in this study were of special-grade.

\section{Production of rice 'Nuruk'}

Five kilograms of each milled rice sample was thoroughly washed and soaked in water for different durations. The soaking duration was determined based on investigations on the water absorption rate of rice depending on the degrees of milling. Next, the rice was drained for $1 \mathrm{~h}$, placed in a preheated cooker (MS-30, Yaegaki Food \& System Inc., Himeji, Japan), and then steamed for $1 \mathrm{~h}$. After steaming, the rice was cooled to $50^{\circ} \mathrm{C}$, and $0.01 \%$ A. oryzae starter (compared to the amount of rice) was aseptically inoculated into the riece and mixed well for sufficient absorption. The samples were then incubated for $43 \mathrm{~h}$ in an incubator (VS-1203PFHLN, Vision Scientific, Co., Ltd., Daejeon, Korea) $\left(35^{\circ} \mathrm{C}, 98 \%\right.$ relative humidity). Throughout incubation, the samples were turned over at 13,15, 21, and $27 \mathrm{~h}$ to lower the temperature of the samples and improve mixing. After incubation, the 'Nuruk' was evenly spread out at room temperature $\left(25^{\circ} \mathrm{C}\right)$ and dried for $1 \mathrm{~h}$.

\section{Analysis of general components or rice and rice 'Nuruk'}

The moisture contents of rice and rice 'Nuruk' following different degrees of milling were measured using a moisture analyzer (AND MX-50, AND Company Ltd., Tokyo, Japan). To measure the starch values of rice with different degrees of milling based on a previously reported procedure (Kim et al., 2011), $1 \mathrm{~g}$ of each ground sample was mixed with 300 $\mathrm{mL}$ of water and $15 \mathrm{~mL}$ of concentrated hydrochloric acid $(35 \%)$. This mixture was steamed at $100^{\circ} \mathrm{C}$ for $2-3 \mathrm{~h}$ in an autoclave. The samples were then cooled with cold water, and the $\mathrm{pH}$ was adjusted to $4.3-4.5$ using $20 \% \mathrm{NaOH}$; the total volume of each sample was then adjusted to $500 \mathrm{~mL}$. This sample was referred to as the saccharification liquid and was used to measure the reducing sugar content using a modified dinitrosalicylic acid (DNS) method (Luchsinger and Cornesky, 1962). Next, $3 \mathrm{~mL}$ of the DNS reagent was added to $1 \mathrm{~mL}$ of the diluted saccharification liquid. This mixture was then heated for $5 \mathrm{~min}$ in a water bath (B-490, BUCHI, Flawil, Switzerland) and then quickly cooled. Subsequently, $5 \mathrm{~mL}$ of distilled water was added to this sample, and the absorbance was measured at $550 \mathrm{~nm}$ using a UV-visible spectrophotometer (JP/UV-2450, Shimadzu, Kyoto, Japan). The sugar content was determined from a standard curve obtained as described above using glucose (Sigma-Aldrich Co., St. Louis, MO, USA) as a reference. After the reducing sugar content was measured, the starch value was calculated as follows (Editors of brewing society of Japan, 1993).

$$
\text { Starch value }=\frac{\text { reducing sugar } \times 5 \times 0.9}{\mathrm{~g} \text { of ground sample }} \times \frac{1}{10}
$$


The general components of rice and rice 'Nuruk', such as ash, crude fat, and protein as well as vitamin $\mathrm{B}_{2}$ and minerals (Fe and $\mathrm{Mn}$ ), in the samples subjected to different degrees of milling were analyzed using the general test methods outlined in the Korean Food Standards Codex (KFDA, 2015). The ash content was analyzed by the dry heat incineration method using muffle furnace at $550^{\circ} \mathrm{C}$. The crude fat content was measured by the Soxhlet method using diethyl ether after grinding the samples. The crude protein content was measured by the Kjeldahl method. All analyses were repeated thrice.

\section{Increased moisture content of rice with different degrees of milling by hydration}

The increase in the moisture content of the rice samples subjected to different degrees of milling was analyzed according to a procedure described by Kim and Jeon (1996). First, $50 \mathrm{~g}$ of each rice sample was soaked in water at room temperature $\left(25^{\circ} \mathrm{C}\right)$ and hydrated at a constant interval. The samples were then rolled on filter paper (No.1, Advantec Co., Ltd., Tokyo, Japan) to remove water from the surface, and the resulting increase in weight was measured.

\section{Physicochemical analysis of water extract of rice 'Nuruk'}

First, $20 \mathrm{~g}$ of rice 'Nuruk' was placed in a $200 \mathrm{~mL}$ Erlenmeyer flask, to which $100 \mathrm{~mL}$ of distilled water was then added. The flask was sealed with plastic wrap and at room temperature $\left(25^{\circ} \mathrm{C}\right)$ for $3 \mathrm{~h}$ with occasional mixing for extraction. The sample was then filtered using filter paper (No.2, Advantec Co., Ltd., Tokyo, Japan), and the filtrate was used for the following experiment. The $\mathrm{pH}$ of the filtrate was measured using a $\mathrm{pH}$ meter (Orion 3 Star Benchtop pH meter, Thermo Fisher Scientific Inc., Waltham, MA, USA), and the acidity was measured based on the volume (in $\mathrm{mL}$ ) of $0.1 \mathrm{~N} \mathrm{NaOH}$ used to titrate $10 \mathrm{~mL}$ of the filtrate until the color of the sample changed to light green (Editors of Brewing Society of Japan, 1993). To measure the amino acidity, $10 \mathrm{~mL}$ of the filtrate was added to a flask and titrated against $0.1 \mathrm{~N} \mathrm{NaOH}$ until the color changed to light pink. Next, $5 \mathrm{~mL}$ of a neutral formalin solution was added to restore the original color of the sample. Again, $0.1 \mathrm{~N} \mathrm{NaOH}$ was added until the light pink color appeared, and the total amount of titrating solution used was determined. The soluble solid content ( ${ }^{\circ}$ Brix) was measured using a digital refractometer (PR-201, Atago Co., Tokyo, Japan). The reducing sugar content was measured using a modified DNS method.

\section{Enzymatic activities of rice 'Nuruk' with different degrees of milling}

Enzymes were extracted from rice 'Nuruk' as follows. To $10 \mathrm{~g}$ of rice 'Nuruk', $50 \mathrm{~mL}$ of $10 \mathrm{mM}$ acetic acid buffer (pH 5.0) containing $0.5 \% \mathrm{NaCl}$ was added and shaken occasionally at room temperature $\left(25^{\circ} \mathrm{C}\right)$ for $3 \mathrm{~h}$ for extraction. The mixture was filtered using filter paper (No. 5C, Advantec Co., Ltd., Tokyo, Japan), and the filtrate was diluted and used as enzymatic activity samples (Editors of Brewing Society of Japan, 1993).

The activities of $\alpha$-amylase, glucoamylase, and acidic protease of rice 'Nuruk' with different degrees of milling were measured using an analytical method described in the foodtnotes of the National Tax Agency analytical method (Editors of Brewing Society of Japan, 1993; Kim et al., 2010).

$\alpha$-Amylase First, $2 \mathrm{~mL}$ of a $1 \%$ starch (Wako Pure Chemical Industrial, Ltd., Osaka, Japan) solution was preheated at $40^{\circ} \mathrm{C}$ for $5 \mathrm{~min}$, and then $0.1 \mathrm{~mL}$ of the enzyme solution was added. Next, $0.1 \mathrm{~mL}$ of the mixer was removed at $0 \min \left(\mathrm{T}_{0}\right)$ and after $30 \mathrm{~min}\left(\mathrm{~T}_{30}\right)$, each of these samples was added to $10 \mathrm{~mL}$ of an iodine solution (Iodine, Sigma Chemical Co., St. Louis, MO, USA). The penetration ratio $(\mathrm{T} \%)$ of the mixture was determined at $670 \mathrm{~nm}$ using a UV-visible spectrophotometer. The enzyme activity was calculated using the following equation.

Enzyme activity (unit/g)

$$
=12.75 \times\left(\mathrm{T}_{30}-\mathrm{T}_{0}\right) / 30 \times 100 / 10 \text { (dilution rate) }
$$

Glucoamylase First, $1 \mathrm{~mL}$ of a $2 \%$ starch (Wako Pure Chemical Industrial, Ltd., Osaka, Japan) solution was preheated with $0.2 \mathrm{~mL}$ of a $0.2 \mathrm{~mol}$ sodium acetate buffer at $40^{\circ} \mathrm{C}$ for $5 \mathrm{~min}$. Then, $0.1 \mathrm{~mL}$ of the enzyme solution was added. The sample was activated at $40^{\circ} \mathrm{C}$ for $20 \mathrm{~min}$. Then, $0.1 \mathrm{~mL}$ of a $1 \mathrm{~N}$ sodium hydroxide solution was added to stop the reaction. After $30 \mathrm{~min}, 0.1 \mathrm{~mL}$ of $1 \mathrm{~N} \mathrm{HCl}$ (Junsei Chemical Co., Tokyo, Japan) was added to neutralize the solution. The content of glucose was measured using a modified DNS method. The enzyme activity was calculated using the following equation. 
Enzyme activity (unit/g)

$=$ produced glucose $(\mathrm{mg}) \times 60 / 20$ (reaction time $) \times 1 / 0.1$ $($ enzyme solution $) \times 100 / 10$ (dilution rate $)$

Acidic protease First, $1.5 \mathrm{~mL}$ of a casein solution was preheated with $1.0 \mathrm{~mL}$ of $\mathrm{pH} 3.0$ Mcllvaine buffer at $40^{\circ} \mathrm{C}$ for $5 \mathrm{~min}$. Next, $0.5 \mathrm{~mL}$ of the enzyme solution was added, and the solution was activated at $40^{\circ} \mathrm{C}$ for $60 \mathrm{~min}$. Then, $0.1 \mathrm{~mL}$ of $0.4 \mathrm{M}$ trichloroacetic acid was added to stop the reaction, and the precipitate was removed. Afterward, $1 \mathrm{~mL}$ of this reaction solution was reacted with $5 \mathrm{~mL}$ of $0.4 \mathrm{M}$ $\mathrm{Na}_{2} \mathrm{CO}_{3}$ and $1 \mathrm{~mL}$ of a phenol reagent at $40^{\circ} \mathrm{C}$ for $30 \mathrm{~min}$ to produce a color change. Then, the absorbance of each sample at $660 \mathrm{~nm}$ was measured. As a control, the enzyme solution was added immediately before the addition of 0.1 $\mathrm{mL}$ of $0.4 \mathrm{M}$ trichloroacetic acid. The solution was then allowed to react, and the absorbance was measured as described above. The difference in the absorbances of the test solution and the control solution was y $(\mu \mathrm{g})$, which was obtained from a calibration curve of tyrosine. The enzyme activity was calculated using the following equation.

\section{Enzyme activity (unit/g)}

$=\mathrm{y}(\mu \mathrm{g}) \times 6 / 1($ reaction solution) $\times 1 / 0.5$ (enzyme solution $) \times 100 / 10$ (dilution rate)

\section{Statistical analysis}

All data were measured in triplicate and expressed as the mean \pm SD. For the statistical analysis, SPSS (version 12.0, SPSS, Inc., Chicago, IL, USA) was used to perform one-way ANOVA. When significant differences between samples were detected, Duncan's multi-range test was performed at $\alpha=0.05$. Additionally, correlation analysis, and paired t-test were performed to analyze the correlation between samples.

\section{Results and discussion}

\section{Water absorption rate and moisture content of rice with different degrees of milling}

An important step in making 'Nuruk' is the optimal production of useful enzymes by the mold starter. Hence, controlling the moisture content in steamed rice is crucial (Jeong, 2012). Moisture content of $35-38 \%$ is desirable in steamed rice. To obtain steamed rice with desirable moisture content, rice (moisture content: 12.5\%) must be soaked in water until the water absorption rate reaches $25 \%$. Therefore, to determine the soaking time before producing rice 'Nuruk', the water absorption rate and moisture content of rice with different degrees of milling were measured until equilibrium was reached (Fig. 1). The hydration of the rice samples exhibited variations depending on the degree of milling. When soaked in water at $25^{\circ} \mathrm{C}$, polished rice without milling reached equilibrium within $20 \mathrm{~min}$ with a moisture content of $30 \%$. The other treatment groups typically reached equilibrium after $10 \mathrm{~min}$ of soaking. The moisture contents of such groups were also higher than that of polished rice without milling. In particular, rice with 50\% milling had a higher moisture content than the other treatment groups after $10 \mathrm{~min}$ of soaking. Similar to the results from a study by Mok et al. (1983), who examined
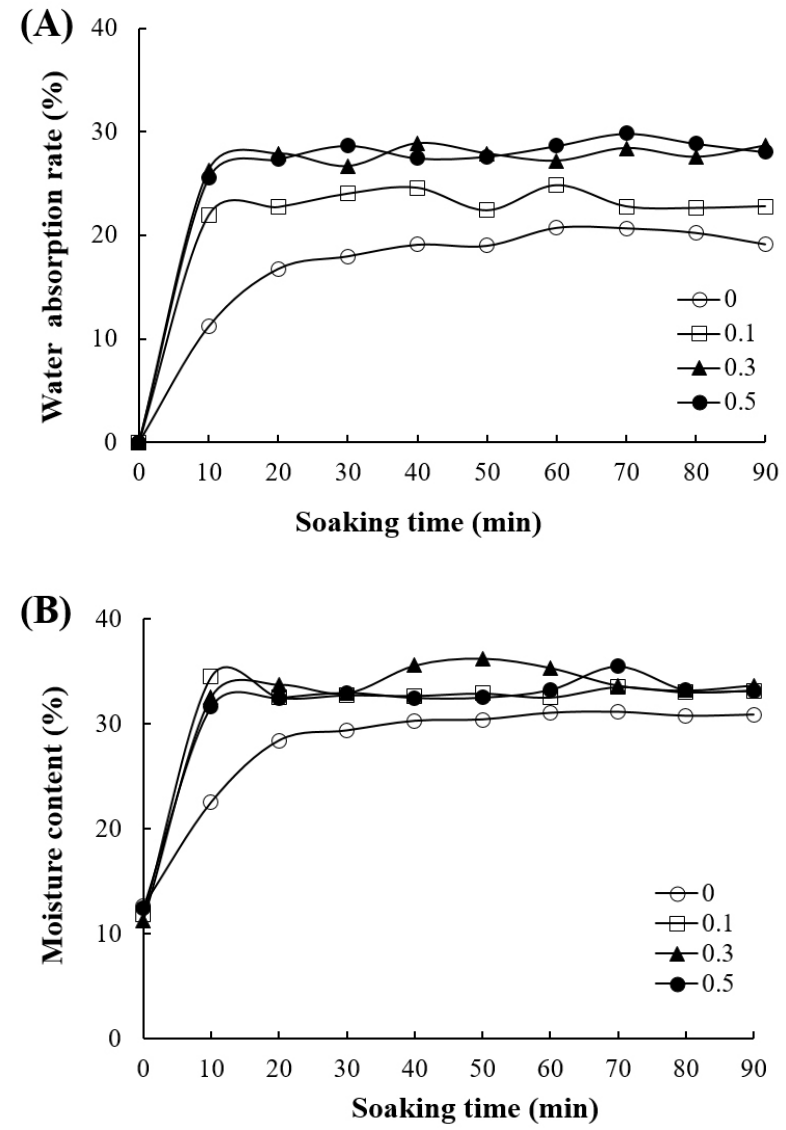

Fig. 1. Changes of moisture content during soaking at $25^{\circ} \mathrm{C}$.

(A), Changes of water absorption rate (\%); (B), Changes of moisture content. $0 \%, 10 \%, 30 \%$, and $50 \%$ mean degree of milling of rice. 
the hydration properties of barley with different degrees of milling and reported that the hydration rate increased as the degree of milling increased, our results suggest that milling affects the water absorption rate and time of rice. Thus, the water soaking time in the water was set to $20 \mathrm{~min}$ for polished rice without milling and $10 \mathrm{~min}$ for the other treatment groups.

\section{Moisture content (\%) of rice and rice 'Nuruk' with degree of milling}

The moisture content of rice with different degrees of milling ranged from $11.04 \%$ to $12.68 \%$, with the moisture content significantly decreasing as the degree of milling increased (Fig. 2). By contrast, the moisture contents of 'Nuruk' after soaking in water for a set duration ranged from $31.99 \%$ to $37.47 \%$, and the moisture content after steaming ranged from $31.79 \%$ to $34.27 \%$ depending on the degree of milling. These results indicated a significant increase in the moisture content as the degree of milling increased. Particularly, the moisture content of steamed rice is important because the moisture content is associated with the proliferation of mold and enzyme production in 'Nuruk'. A previous study (Bae, 2008) reported that mold proliferation becomes challenging when the water content in steamed rice is low. However, when the water absorption rate of steamed rice is higher than $24 \%$, the growth rate is not affected (Bae, 2008). We found that excessive moisture content reduced

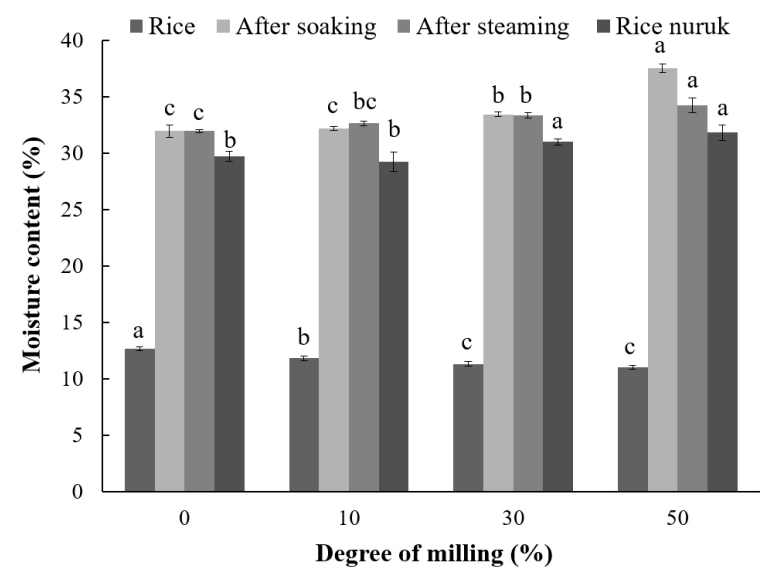

Fig. 2. Moisture content (\%) of rice and rice 'Nuruk' as affected by degree of milling.

Values represent the mean $\pm \mathrm{SD}(\mathrm{n}=3)$. Means with different letters $\left({ }^{\mathrm{a}-\mathrm{c}}\right)$ above the bars are significantly different at the $p<0.05$ by Duncan's multiple range test. the enzyme production in steamed rice. This may be because the increase in glucose during steaming inhibits the production of hydrolytic enzymes. Therefore, to obtain 'Nuruk' with high activity, controlling the moisture content of steamed rice is important, and proper control of the moisture content of steamed rice begins in the soaking step. The experimental results revealed that the moisture content of the steamed rice was within the range wherein the growth rate of mold is unaffected.

\section{Starch value (\%) of rice with different degree of milling}

The starch value, which is the mass of starch in $100 \mathrm{~g}$ of a sample, accounts for sugars, dextrin, and starch. A higher starch content indicates higher production of sugar components and is associated with a higher alcohol yield in alcohol fermentation (Kim et al., 2011; Lee et al., 2013). The starch values of rice with different degrees of milling were analyzed to determine the effect of milling on the properties of 'Nuruk'. The starch values of the samples ranged from $85.13 \%$ to $90.99 \%$ and increased as the degree of milling increased. Regression analysis and one way ANOVA, revealed that the degree of milling significantly affected the starch value $(p<0.05)$ (Fig. 3). We calculated that when the degree of milling was increased by $1 \%$, the starch content increased by $1.887 \%$ with an explanatory power of $71.8 \%$ (according to correlation data between the starch value and the degree of milling, data not shown).

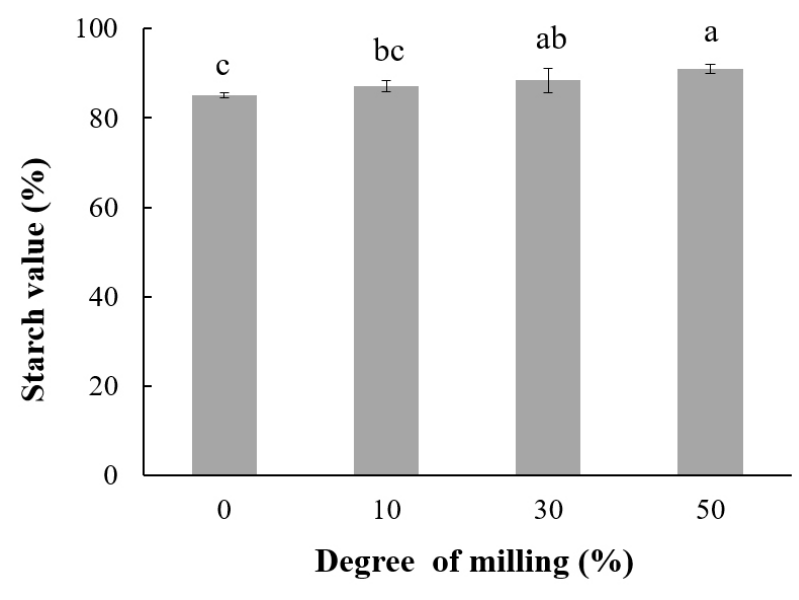

Fig. 3. Starch value (\%) of rice as affected by degree of milling. Values represent the mean \pm SD $(n=3)$. Means with different letters $\left({ }^{\mathrm{a}-\mathrm{c}}\right)$ above the bars are significantly different at the $p<0.05$ by Duncan's multiple range test. 
Crude protein, crude fat, vitamin, and mineral contents of rice and rice 'Nuruk' with different degrees of milling

Our results were in agreement with those of Kim and Jeon (1996) which determined that the general components such as protein, ash, and fat decreased as the degree of milling of rice increased, because such components are mostly distributed in the outer layer of rice. A study by Ke (1966) analyzed the changes in the components of rice depending on the degree of milling and determined that the contents of nutrients decreased as the degree of milling increased. Analysis of the components in rice 'Nuruk' with different degrees of milling showed that all components, other than crude fat, significantly decreased as the degree of milling increased. The crude fat and iron contents differed from the contents of the other components depending on the degree of milling (Table 1). As shown by the paired t-test to compare the components of rice and rice 'Nuruk' depending on the degree of milling, the crude protein content significantly decreased for all treatments groups. Crude fat showed significant differences only for $0 \%$ milled 'Nuruk', which was not milled, whereas crude ash showed significant differences for $30 \%$ and $50 \%$ milled 'Nuruk' (data not shown). This result is likely because Aspergillus used these components for growth, which would account for the difference between the amounts of these components in rice and 'Nuruk'.

\section{Physicochemical properties of rice 'Nuruk' with different degrees of milling}

The $\mathrm{pH}$ was the lowest (5.32) in rice 'Nuruk' with $0 \%$ milling and highest (5.98) in rice 'Nuruk' with 30\% milling. This result indicated that there is no correlation between the degree of milling and $\mathrm{pH}$. There was also no clear trend in the acidity with respect to the degree of milling (Table 2). The soluble solid and reducing sugar increased as the degree of milling increased, such values were correlated with the starch values in rice with different degrees of milling

Table 1. Contents (\%) of different constituents of rice and rice 'Nuruk' as affected by the degree of milling

\begin{tabular}{|c|c|c|c|c|c|c|c|}
\hline \multirow{2}{*}{\multicolumn{2}{|c|}{ Degree of milling $(\%)$}} & \multirow{2}{*}{$\begin{array}{c}\text { Crude protein } \\
(\%)\end{array}$} & \multirow{2}{*}{$\begin{array}{l}\text { Crude lipid } \\
(\%)\end{array}$} & \multirow{2}{*}{$\begin{array}{l}\text { Ash } \\
(\%)\end{array}$} & \multirow{2}{*}{$\begin{array}{l}\text { Vitamin } B_{2} \\
(\mathrm{mg} / 100 \mathrm{~g})\end{array}$} & \multicolumn{2}{|c|}{ Mineral (mg/100 g) } \\
\hline & & & & & & $\mathrm{Fe}$ & $\mathrm{Mn}$ \\
\hline \multirow{4}{*}{ Rice } & 0 & $6.22 \pm 0.11^{\mathrm{al})}$ & $0.40 \pm 0.01^{\mathrm{a}}$ & $0.30 \pm 0.07$ & $0.04 \pm 0.00$ & $0.93 \pm 0.25$ & $1.38 \pm 0.03^{\mathrm{a}}$ \\
\hline & 10 & $5.85 \pm 0.14^{\mathrm{b}}$ & $0.02 \pm 0.00^{\mathrm{b}}$ & $0.28 \pm 0.00$ & $0.04 \pm 0.00$ & $0.77 \pm 0.02$ & $1.15 \pm 0.01^{\mathrm{b}}$ \\
\hline & 30 & $5.56 \pm 0.06^{\mathrm{c}}$ & $0.01 \pm 0.00^{\mathrm{c}}$ & $0.23 \pm 0.01$ & $0.04 \pm 0.00$ & $0.70 \pm 0.02$ & $1.06 \pm 0.02^{\mathrm{c}}$ \\
\hline & 50 & $5.38 \pm 0.09^{c}$ & $0.01 \pm 0.00^{\mathrm{c}}$ & $0.22 \pm 0.01$ & $0.04 \pm 0.00$ & $0.63 \pm 0.07$ & $1.03 \pm 0.01^{\mathrm{c}}$ \\
\hline \multirow{4}{*}{$\begin{array}{l}\text { Rice } \\
\text { 'Nuruk' }\end{array}$} & 0 & $5.04 \pm 0.02^{\mathrm{a}}$ & $0.02 \pm 0.00$ & $0.18 \pm 0.01^{\mathrm{a}}$ & $0.13 \pm 0.01^{\mathrm{a}}$ & $0.64 \pm 0.03^{\mathrm{a}}$ & $0.88 \pm 0.01^{\mathrm{a}}$ \\
\hline & 10 & $4.52 \pm 0.03^{b}$ & $0.01 \pm 0.00$ & $0.14 \pm 0.00^{\mathrm{b}}$ & $0.10 \pm 0.00^{\mathrm{b}}$ & $0.62 \pm 0.04^{\mathrm{a}}$ & $0.77 \pm 0.04^{\mathrm{b}}$ \\
\hline & 30 & $4.41 \pm 0.01^{\mathrm{c}}$ & $0.01 \pm 0.00$ & $0.12 \pm 0.00^{\mathrm{c}}$ & $0.10 \pm 0.00^{\mathrm{b}}$ & $0.54 \pm 0.00^{\mathrm{b}}$ & $0.77 \pm 0.05^{\mathrm{b}}$ \\
\hline & 50 & $4.25 \pm 0.03^{\mathrm{d}}$ & $0.01 \pm 0.00$ & $0.13 \pm 0.02^{\mathrm{bc}}$ & $0.09 \pm 0.00^{\mathrm{b}}$ & $0.50 \pm 0.01^{\mathrm{b}}$ & $0.70 \pm 0.02^{\mathrm{b}}$ \\
\hline
\end{tabular}

${ }^{1)}$ Means \pm SD ( $\left.n=3\right)$ within each column followed by different letters are significantly different $(\mathrm{p}<0.05)$.

Table 2. Physicochemical properties of rice 'Nuruk' as affected by the degree of milling

\begin{tabular}{cccccc}
\hline $\begin{array}{c}\text { Degree of milling } \\
(\%)\end{array}$ & $\mathrm{pH}$ & $\begin{array}{c}\text { Acidity } \\
(\mathrm{mL})\end{array}$ & $\begin{array}{c}\text { Soluble solid } \\
\left({ }^{\circ} \text { Brix }\right)\end{array}$ & $\begin{array}{c}\text { Amino acidity } \\
(\mathrm{mL})\end{array}$ & $\begin{array}{c}\text { Reducing sugar } \\
(\mathrm{mg} / \mathrm{mL})\end{array}$ \\
\hline 0 & $5.32 \pm 0.04^{\mathrm{d} 1)}$ & $0.64 \pm 0.04^{\mathrm{a}}$ & $5.93 \pm 0.06^{\mathrm{c}}$ & $1.58 \pm 0.05^{\mathrm{a}}$ & $3.04 \pm 0.02^{\mathrm{d}}$ \\
10 & $5.78 \pm 0.17^{\mathrm{b}}$ & $0.49 \pm 0.05^{\mathrm{b}}$ & $6.00 \pm 0.00^{\mathrm{c}}$ & $1.49 \pm 0.07^{\mathrm{b}}$ & $3.19 \pm 0.01^{\mathrm{c}}$ \\
30 & $5.98 \pm 0.02^{\mathrm{a}}$ & $0.49 \pm 0.02^{\mathrm{b}}$ & $6.33 \pm 0.06^{\mathrm{b}}$ & $1.51 \pm 0.01^{\mathrm{ab}}$ & $3.29 \pm 0.06^{\mathrm{b}}$ \\
50 & $5.53 \pm 0.04^{\mathrm{c}}$ & $0.73 \pm 0.11^{\mathrm{a}}$ & $6.60 \pm 0.00^{\mathrm{a}}$ & $1.46 \pm 0.02^{\mathrm{b}}$ & $3.43 \pm 0.07^{\mathrm{a}}$ \\
\hline
\end{tabular}

\footnotetext{
${ }^{1)}$ Means \pm SD ( $n=3$ ) within each column followed by different letters are significantly different $(\mathrm{p}<0.05)$.
} 
(correlation coefficient: 0.825 , Table 3 ). The acidity generally decreases upon milling and correlates with the protein content in rice. (Baek et al., 2011). In this study, however, the acidity did not seem to be correlated with the protein content in rice.

\section{Enzymatic activities in rice 'Nuruk' with different degrees of milling}

During proliferation, A. oryzae obtains nutrients required for proliferation from steamed rice. Therefore, A. oryzae secretes various enzymes such as starch-degrading enzymes, proteases, and lipases (Bae, 2008). The main enzymes involved in brewing include $\alpha$-amylase, glucoamylase, and acidic protease. Thus, the activity of each enzyme was analyzed according to the degree of milling. $\alpha$-Amylase is an enzyme that liquefies the starch in steamed rice during brewing. When the starch in steamed rice does not dissolve, many lees are generated (Bae, 2008). The $\alpha$-amylase activity

Table 3. Pearson's correlation coefficient between components of rice and characteristics of rice 'Nuruk'

\begin{tabular}{|c|c|c|c|c|c|c|c|c|c|c|c|c|c|c|c|c|}
\hline & $\begin{array}{l}\text { Moisture } \\
\text { content } \\
\text { of } \\
\text { steamed } \\
\text { rice }\end{array}$ & $\begin{array}{l}\text { Starch } \\
\text { value }\end{array}$ & $\begin{array}{l}\text { Crude } \\
\text { lipid }\end{array}$ & $\begin{array}{c}\text { Crude } \\
\text { protein }\end{array}$ & Ash & $\begin{array}{c}\text { Vitamin } \\
\mathrm{B}_{2}\end{array}$ & $\mathrm{Fe}$ & $\mathrm{Mn}$ & $\mathrm{pH}$ & Acidity & $\begin{array}{c}\text { Soluble } \\
\text { solid }\end{array}$ & $\begin{array}{l}\text { Amino } \\
\text { acidity }\end{array}$ & $\begin{array}{l}\text { Reducing } \\
\text { sugar }\end{array}$ & $\begin{array}{c}\alpha- \\
\text { Amylase }\end{array}$ & $\begin{array}{l}\text { Gluco- } \\
\text { amylase }\end{array}$ & $\begin{array}{c}\text { Acidic } \\
\text { protease }\end{array}$ \\
\hline $\begin{array}{l}\text { Moisture } \\
\text { content of } \\
\text { steamed } \\
\text { rice }\end{array}$ & 1 & $.914^{* * 1)}$ & $-.712^{* *}$ & $-.868^{* *}$ & $-.701^{*}$ & -.681 & -.597 & $-.853^{* *}$ & .248 & .292 & $.910^{* *}$ & $-.664^{*}$ & $.860^{* *}$ & .370 & $-.862^{* *}$ & .308 \\
\hline $\begin{array}{l}\text { Starch } \\
\text { value }\end{array}$ & & 1 & $-.656^{*}$ & $-.823^{* *}$ & $-.611^{*}$ & -.478 & -.515 & $-.722^{*}$ & .191 & .324 & $.825^{* *}$ & $-.721^{* *}$ & $.825^{* *}$ & .282 & $-.881^{* *}$ & .486 \\
\hline $\begin{array}{l}\text { Crude } \\
\text { lipid }\end{array}$ & & & 1 & $-.834^{* *}$ & .540 & $.832^{*}$ & .702 & $.944^{* *}$ & $-.736^{* *}$ & .248 & $-.622^{*}$ & $.706^{*}$ & $-.782^{* *}$ & .003 & $.630^{*}$ & $-.608^{*}$ \\
\hline $\begin{array}{l}\text { Crude } \\
\text { protein }\end{array}$ & & & & 1 & $-.793^{* *}$ & $.732^{*}$ & $.864^{* *}$ & $.941^{* *}$ & -.432 & -.125 & $-.911^{* *}$ & $.696^{*}$ & $-.926^{* *}$ & -.306 & $.821^{* *}$ & -.530 \\
\hline Ash & & & & & 1 & $.730^{*}$ & $.892^{* *}$ & .683 & -.279 & -.195 & $-.790^{* *}$ & .260 & $-.656^{*}$ & -.213 & .551 & -.324 \\
\hline $\begin{array}{c}\text { Vitamin } \\
\mathrm{B}_{2}\end{array}$ & & & & & & 1 & $.812^{*}$ & $.837^{*}$ & -.528 & .043 & -.582 & .422 & -.635 & .108 & .413 & -.316 \\
\hline $\mathrm{Fe}$ & & & & & & & 1 & $.805^{*}$ & -.358 & -.076 & $-.736^{*}$ & .395 & $-.720^{*}$ & -.009 & .449 & -.533 \\
\hline $\mathrm{Mn}$ & & & & & & & & 1 & -.616 & .013 & $-.827^{*}$ & .703 & $-.860^{* *}$ & -.261 & .633 & -.698 \\
\hline $\mathrm{pH}$ & & & & & & & & & 1 & $-.682^{*}$ & .202 & -.191 & .340 & .042 & -.151 & $.721^{* *}$ \\
\hline Acidity & & & & & & & & & & 1 & .403 & -.217 & .289 & .169 & -.285 & -.372 \\
\hline $\begin{array}{l}\text { Soluble } \\
\text { solid }\end{array}$ & & & & & & & & & & & 1 & -.557 & $-.904^{* *}$ & .449 & $-.767^{* *}$ & .335 \\
\hline $\begin{array}{l}\text { Amino } \\
\text { acidity }\end{array}$ & & & & & & & & & & & & 1 & $-.710^{* *}$ & -.101 & $.775^{* *}$ & -.340 \\
\hline $\begin{array}{l}\text { Reducing } \\
\text { sugar }\end{array}$ & & & & & & & & & & & & & 1 & .346 & $-.808^{* *}$ & .510 \\
\hline $\begin{array}{c}\alpha- \\
\text { Amylase }\end{array}$ & & & & & & & & & & & & & & 1 & .405 & .236 \\
\hline $\begin{array}{l}\text { Gluco- } \\
\text { amylase }\end{array}$ & & & & & & & & & & & & & & & 1 & -.377 \\
\hline $\begin{array}{c}\text { Acidic } \\
\text { protease }\end{array}$ & & & & & & & & & & & & & & & & 1 \\
\hline
\end{tabular}


of the $10 \%$ milled rice 'Nuruk' is presumed to have resulted from an experimental error, and the $\alpha$-amylase activity of the rice 'Nuruk' with a higher degree of milling was decreased (Fig. 4). Glucoamylase is also known as a diastatic enzyme because it breaks the non-reducing end group of the starch $\alpha-1,4$ bond to yield glucose; yeast then converts glucose into alcohol via fermentation, which is as an important indicator for evaluating 'Nuruk' (Bae, 2008). The glucoamylase activity was highly affected by the degree
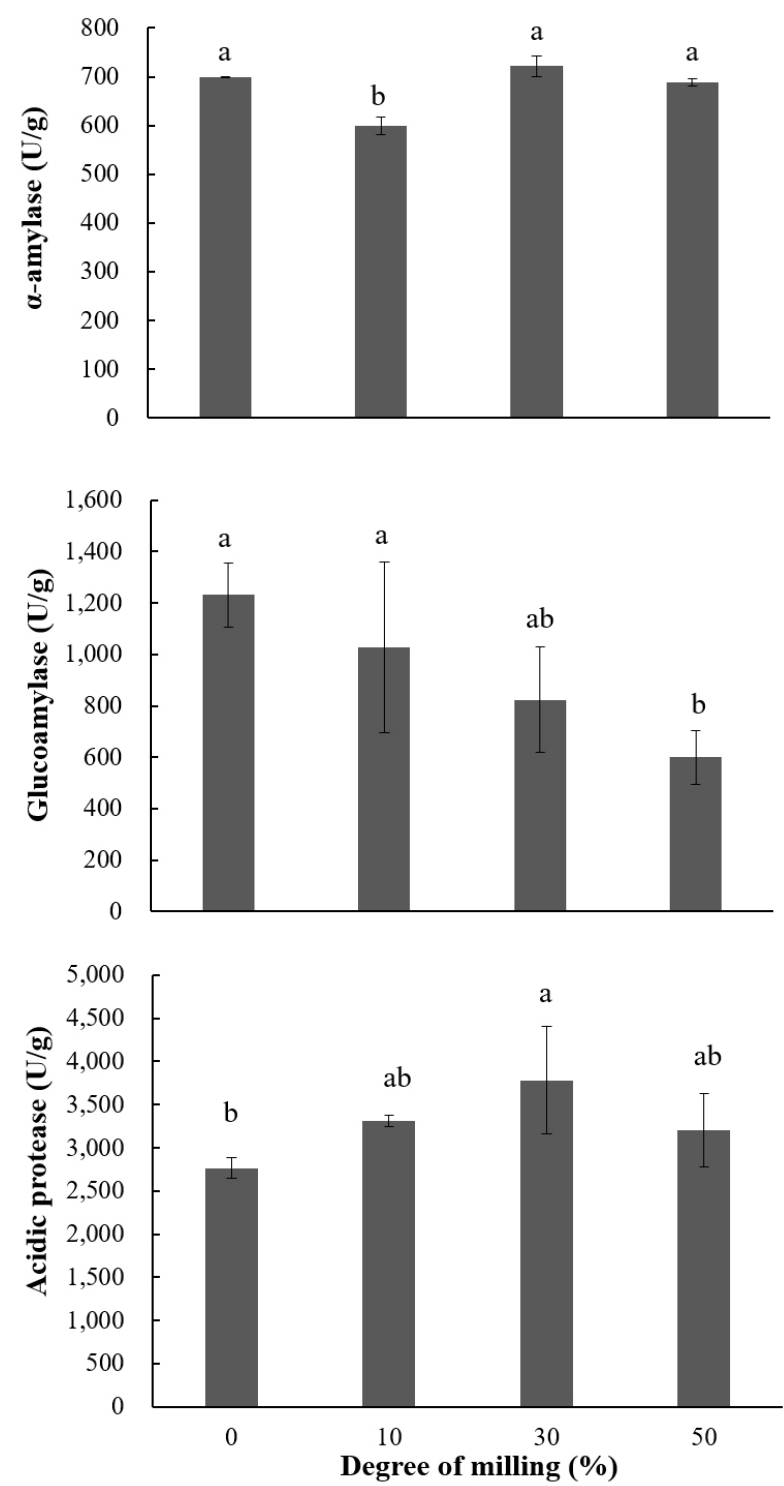

Fig. 4. Enzyme activities of rice 'Nuruk' as affected by the degree of milling.

Values represent the mean \pm SD $(n=3)$. Means with different letters $\left({ }^{a, b}\right)$ above the bars are significantly different at the $p<0.05$ by Duncan's multiple range test. of milling, and significantly decreased as the degree of milling increased (Fig. 4). Acidic protease hydrolyzes proteins and produces low-molecular weight watersoluble peptones. This imparts a pleasant taste and promotes the saccharification of rice starch (Jeong, 2012). In addition, acidic protease degrades proteins and produces alcoholic beverages with five balanced flavors. L-glutamic acid is a flavor component present in natural food products and contributes to the overall flavor of food. Aspartic acid is an amino acid that produces a sour taste, and its $\mathrm{Na}$ dissociates in aqueous solutions to produce an umami taste similar to that of L-glutamic acid. Furthermore, arginine, leucine, tyrosine, and phenylalanine have been reported to produce a bitter taste, but this taste may be favorable for the flavor of alcoholic beverages. Thus, the flavor of alcoholic beverages arises from the combination of amino acids with five flavors (Lee et al., 1991). Moreover, acidic protease is required for diastatic enzymes to be in a state that enables them to act on the starch of steamed rice (Bae, 2008). Acidic protease is an essential enzyme for brewing. Analysis of acidic protease enzymatic activities in rice 'Nuruk' with different degrees of milling (Fig. 4) showed that although there was no clear trend with respect to the degree of milling, 'Nuruk' produced from $30 \%$ milled rice showed the highest enzymatic activity. Hence, such a high expression of acidic protease may be associated with a component contained in $30 \%$ milled rice.

\section{Correlation between the components of milled rice and physicochemical properties and enzymatic activities of rice 'Nuruk'}

Analysis of the correlation between the moisture content of steamed rice and the enzymatic activity revealed that the activity of glucoamylase significantly decreased as the moisture content of the steamed rice increased (Table 3). This result is likely because hydrolytic enzymes produced by Aspergillus sp. were inhibited as the amount of glucose increased in the steamed rice (Bae, 2008). As shown in Table 3, the correlation coefficient between the reducing sugar content and the moisture content of steamed rice was 0.860 , suggesting a close correlation. This result indicates the level of glucose increased as the moisture content of steamed rice increased. In addition, the activity of glucoamylase decreased as the starch value of rice increased, 
whereas the activity increased as the crude protein content in rice increased. The activity of acidic protease showed a negative correlation with the crude lipid content of rice.

\section{Acknowledgement}

This research was support of cooperative research program for Rural Development Administration in Korea (RDA) (Project No. PJ01279402) and Agricultural Science and Technology for National Institute of Agricultural Science, RDA in Korea (Project No. PJ01259401).

\section{Conflict of interests}

The authors declare no potential conflict of interest.

\section{ORCID}

Jeong-Sil Choi https://orcid.org/0000-0002-9036-0047

Seok Tae Jeong https://orcid.org/0000-0001-9997-2763

\section{References}

Ahn JY, Ha TY. Nutritional superiority of Korean rice. Food Preserv Process, 9, 60-64 (2010)

Bae SM. Sake Manufacture Technology. Issue of Brewing Society of Japan. Woo Gok Publishing Company, Seoul, Korea, p 158, 165-167, 184 (2008)

Baek SY, Kim JY, Yun HJ, Choi JH, Choi HS, Jeong ST, Yeo SH. Quality characteristics of Makgeolli and Nuruk grain inoculated with Aspergillus oryzae N041. J East Asian Soc Dietary Life, 21, 877-881 (2011)

Chun AR, Kim DJ, Yoon MR, Oh SK, Choi IS, Hong HC, Kim YG. Effect of milling degree on the physicochemical and sensory quality of Sogokju. J Korean Soc Food Sci Nutr, 41, 136-142 (2012)

Editors of Brewing Society of Japan. Analysis of alcoholic beverages. Brewing Society of Japan, p 154-157, 221222, 213-214 (1993)

Jeong DH. Science of Nuruk. Yuhansa, Seoul, Korea, p 127, 353-356 (2012)

Ke SY. Studies on the rice milling. (Part 3) The variations of the contents of broken rice and rice bran by milling. Korean Soc Anim Sci Technol, 8, 33-35 (1966)
KFDA. General Test Methods. http://www.foodsafetykorea.go. kr/foodcode/01_02.jsp?idx=263 (Accessed Mar 2015)

Kim AJ, Choi JN, Kim JY, Park SB, Yeo SH, Choi JH, Lee CH. GC-MS based metabolite profiling of rice Koji fermentation by various fungi. Biosci Biotechnol Biochem, 74, 2267-2272 (2010)

Kim HR, Kwon YH, Kim JH, Ahn BH. Quality analysis of diverse rice species for rice products. Korean J Food Sci Technol, 43, 142-148 (2011)

Kim KA, Jeon ER. Physicochemical properties and hydration of rice on various polishing degree. Korean J Food Sci Technol, 28, 959-964 (1996)

Kim SR, Ahn JY, Lee HY, Ha TY. Various properties and phenolic acid contents of rices and rice brans with different milling fractions. Korean J Food Sci Technol, 36, 930-936 (2004)

Kwon YH, Lee AR, Kim HR, Kim JH, Ahn BH. Quality properties of Makgeolli brewed with various rice and Koji. Korean J Food Sci Technol, 45, 70-76 (2013)

Lee DH, Kang HY, Lee YS, Cho CH, Kim SJ, Lee JS. Effects of yeast and Nuruk on the quality of Korean Yakju. Korean J Microbiol Biotechnol, 39, 274-280 (2011)

Lee DH, Lee YS, Cho CH, Seo JS, Park IT, Kim HD, Lim JW. Brewing and fermenting characteristics of Makgeolli produced from high-yielding rice varieties. Korean J Food Sci Technol, 45, 714-720 (2013)

Lee MK, Lee SW, Bae SM. The quality of Yakju be brewed from many kind of Nuruk. J East Asian Soc Dietary Life, 1, 99-111 (1991)

Lee NY. Starch and quality characteristic of Korean rice cultivar with waxy and non-waxy type. Korean J Crop Sci, 58, 226-231 (2013)

Liu L, Guo JJ, Zhang RF, Wei ZC, Deng YY, Guo JX, Zhang MW. Effect of degree of milling on phenolic profiles and cellular antioxidant activity of whole brown rice. Food Chem, 185, 318-325 (2015)

Luchsinger WW, Cornesky RA. Reducing power by the dinitrosalicylic acid method. Anal Biochem, 4, 346-347 (1962)

Mok CK, Lee HY, Nam YJ, Min BY. A kinetic study on the hydration process of barley kernels with various polishing yields. Korean J Food Sci Technol, 15, 136140 (1983) 
Park JH, Chung $\mathrm{CH}$. Characteristics of Takju (a cloudy Korean rice wine) prepared with Nuruk (a traditional

Korean rice wine fermentation starter), and identification of lactic acid bacteria in Nuruk. Korean J Food Sci Technol, 46, 153-164 (2014) 